\title{
A busca do sentido da formação humana: tarefa da Filosofia da Educação
}

Antônio Joaquim Severino

Universidade de São Paulo

\section{Resumo}

0 trabalho desenvolve uma reflexão sobre a educação entendida como processo de formação humana, buscando ver quais os sentidos que essa formação recebeu ao longo de nossa tradição filosófica e na contemporaneidade, uma vez que ocorreram mudanças nas concepções que os homens fizeram do ideal de sua humanização. Sob tal perspectiva, recoloca em discussão as relações entre as diversas dimensões da educabilidade humana, destacando as dimensões ética e política que, até o atual momento, prevaleceram como fundamentos da compreensão da própria natureza da educação e concluindo que hoje a formação humana, visada pela educação, compreende-se como formação cultural. Essa idéia dá à educação uma finalidade intrínseca de cunho mais antropológico do que ético ou político. Essa reflexão sobre a natureza da educação implica igualmente explicitar o lugar e o papel da Filosofia da Educação, como esforço hermenêutico de desvelamento da prática educacional, tal como ela precisa se desenrolar nas mudadas condições histórico-culturais da atualidade. A discussão permite, assim, não apenas interpelar momentos significativos da expressão histórica da Filosofia da Educação na cultura ocidental, mas também debater conteúdos teóricos fundamentais do debate filosófico sobre o sentido da educação, debate que se impõe com renovada força para os educadores no enfrentamento dos desafios que estão sendo colocados pelas novas condições da pós-modernidade, responsável por um profundo questionamento das referências filosóficas da tradição cultural do ocidente.

\section{Palavras-chave}

Filosofia da Educação - Ética - Política - Formação cultural.

\footnotetext{
Correspondência: 


\title{
The search for the meaning of human formation: a task for the philosophy of education
}

\author{
Antônio Joaquim Severino
}

Universidade de São Paulo

\begin{abstract}
The work conducts a reflection on education understood as a process of human formation, trying to perceive the meanings attributed to this formation throughout our philosophical tradition and in contemporaneity, since there have been changes in the conceptions men have made of the ideal of their humanization. Under such perspective, the article brings back to the discussion the relations between the various dimensions of human educability, highlighting the ethical and political dimensions which, until the present moment, have prevailed as the foundations of the understanding of the very nature of education, and reaching the conclusion that human formation today, as targeted by education, is understood as cultural formation. This idea gives education an intrinsic purpose of a character that is more anthropological than ethical or political. Such reflection on the nature of education equally entails making explicit the place and role of the Philosophy of Education as a hermeneutic effort of disclosure of the educational practice as it needs to unfold under today's changed historical-cultural conditions. The discussion thus allows not just to inquire into significant moments of the historical expression of the philosophy of education in Western culture, but also to debate fundamental theoretical contents of the philosophical argument over the meaning of education, an argument that stands with renewed strength before the educators meeting the challenges posed by the new conditions of postmodernity, responsible for a profound examination of the philosophical references of Western cultural tradition.
\end{abstract}

\section{Keywords}

Philosophy of education - Ethics - Politics - Cultural formation.

Contact:

Antônio Joaquim Severino

Rua Raul Pompéia, 905 apto 133

05025-010 - São Paulo - SP

e-mail:ajsev@uol.com.br 
Na cultura ocidental, a educação foi sempre vista como processo de formação humana. Essa formação significa a própria humanização do homem, que sempre foi concebido como um ente que não nasce pronto, que tem necessidade de cuidar de si mesmo como que buscando um estágio de maior humanidade, uma condição de maior perfeição em seu modo de ser humano. Portanto, a formação é processo do devir humano como devir humanizador, mediante o qual o indivíduo natural devém um ser cultural, uma pessoa - é bom lembrar que o sentido dessa categoria envolve um complexo conjunto de dimensões que o verbo formar tenta expressar: constituir, compor, ordenar, fundar, criar, instruirse, colocar-se ao lado de, desenvolver-se, dar-se um ser. É relevante observar que seu sentido mais rico é aquele do verbo reflexivo, como que indicando que é uma ação cujo agente só pode ser o próprio sujeito. Nessa linha, afasta-se de alguns de seus cognatos, por incompletude, como informar, reformar e repudia outros por total incompatibilidade, como conformar, deformar. Converge apenas com transformar... A idéia de formação é pois aquela do alcance de um modo de ser, mediante um devir, modo de ser que se caracterizaria por uma qualidade existencial marcada por um máximo possível de emancipação, pela condição de sujeito autônomo. Uma situação de plena humanidade. A educação não é apenas um processo institucional e instrucional, seu lado visível, mas fundamentalmente um investimento formativo do humano, seja na particularidade da relação pedagógica pessoal, seja no âmbito da relação social coletiva. Por isso, a interação docente é considerada mediação universal e insubstituível dessa formação, tendo-se em vista a condição da educabilidade do homem.

Trata-se, sem dúvida, de um objetivo que soa utópico e de difícil consecução à vista da dura realidade histórica de nossa existência. No entanto, foi sempre um horizonte constantemente almejado e buscado. E ainda o continua sendo mesmo diante das condições atuais da civilização, por mais que estejam marcadas pelo poder de degradação no mun- do técnico e produtivo do trabalho: de opressão na esfera da vida social; e de alienação no universo cultural. Essas condições manifestamse, em que pesem as alegações em contrário de variados discursos, como profundamente adversas à formação, o que tem levado a um crescente descrédito quanto ao papel e à relevância da Educação, como processo intencional e sistemático. No entanto, essa situação degradada do momento histórico-social que atravessamos só faz aguçar o desafio da formação humana, necessária pelas carências ônticas e pela contingência ontológica dos homens, mas possível pela educabilidade humana. Quando se fala, pois, em educação para além de qualquer processo de qualificação técnica, o que está em pauta é uma autêntica Bildung, uma paidéia, formação de uma personalidade integral.

0 objetivo deste ensaio é desenvolver uma reflexão sobre como a educação, na qualidade de processo de formação humana, foi concebida, buscando ver quais os sentidos que essa formação recebeu ao longo de nossa tradição filosófica, uma vez que ocorreram mudanças nas concepções que os homens fizeram do ideal de sua humanização. Sob tal perspectiva, recoloco em discussão as relações entre as diversas dimensões da educabilidade humana, destacando as dimensões ética e política que, até o atual momento, prevaleceram como fundamentos da compreensão da própria natureza da educação. Ao refletir assim sobre a natureza da educação, busco igualmente explicitar o lugar e o papel da Filosofia da Educação como esforço hermenêutico de desvelamento da prática educacional, tal como ela precisa se desenrolar nas mudadas condições histórico-culturais da atualidade. Essa discussão permite assim não apenas interpelar momentos significativos da expressão histórica da filosofia na cultura ocidental, mas também retomar conteúdos teóricos fundamentais do debate filosófico atual sobre o sentido da educação.

0 propósito é o de trazer à tona a questão da natureza da educação em relação à formação ética e à formação política, campos 
da prática humana que sempre foram associados à educação pela reflexão filosófica. E a hipótese que me proponho defender é a de que a educação vem sendo pensada hoje como formação cultural, perspectiva que realiza uma sintese superadora das perspectivas anteriores que a conceberam como formação ética, num primeiro momento, e como formação política num segundo momento. A elaboração desse novo modo de se conceituar a educação, na minha leitura, ocorreu tanto como processo histórico-cultural e como processo de construção lógico-conceitual.

Com efeito, constata-se - no âmbito da história da filosofia, no contexto do desenvolvimento da cultura ocidental que, num primeiro momento histórico-teórico, identificável com os períodos da Antiguidade grega e da Medievalidade latina - que a ética prevaleceu como matriz paradigmática da formação humana, ou seja, o ideal humano era o aprimoramento ético-pessoal e esta era a finalidade essencial da educação. Já num segundo momento, historicamente situado na Era Moderna, esse ideal se delineava como uma adequada inserção da pessoa na sociedade. A política era a grande matriz. E agora, no momento histórico recente da contemporaneidade, a reflexão filosófica passa por uma inflexão nesse modo de se conceber a própria idéia da formação humana e, conseqüentemente, também se transforma o modo de se ver a educação. Mesmo sem a nitidez das perspectivas anteriores, o que parece estar se delineando é uma dimensão do formar que afirma, nega e supera as perspectivas éticas e políticas da educação, tais quais delineadas ao longo da nossa tradição filosófica ocidental. Sem perder as imprescindíveis referências éticas e políticas, mais que se afirmar como processo de formação de um sujeito ético ou de um sujeito cidadão, o que está em pauta é a própria construção do sujeito humano no tempo histórico e no espaço social, como sujeito integralmente ético e político, pessoa-habitante de um universo coletivo. Para o olhar da contemporânea Filosofia da Educação, o homem, ser em devir, ser inacabado e lacunar, não tem um ideal a ser buscado ou a ser realizado, mas encontrase condenado a construir para si uma configuração própria não prevista nem previsível, como se tivesse que dar a si mesmo uma destinação. E assim tanto a ética como a política perdem suas, até então, exacerbadas autonomia e preponderância como referências básicas isoladas para a prática educacional. Agora, nessa prática, o homem não se desenha mais como um ser pessoal, desempenhando um modelo de ação, nem como puro ser social, membro devidamente adequado à sociedade, tal parece ser o significado que vem tomando hoje, no quadro da filosofia contemporânea, o próprio conceito de formação, perspectiva articulada particularmente pela Teoria Crítica da Escola de Frankfurt, marco referencial da emergência do modo atual de filosofar. Sem dúvida, ao longo dos três milênios da expressão cultural da filosofia no Ocidente, ética e política sempre apareceram como referentes da educação. Já a Antiguidade expressava explicitamente essa relação tanto quanto a Modernidade nunca descartara a referência à ética. Também hoje continua recorrente a presença dessas perspectivas nos discursos educacionais. No entanto, nesses três momentos, sua força significadora assume conotações específicas diferenciadoras em função do papel que assumem nessa relação.

Em que pese a forte inspiração da matriz frankfurtiana dessa reflexão, meu ângulo de abordagem centra a atenção no significado da educação, tal qual eu o vejo no processo de constituição teórica no âmbito da atual tendência da Filosofia da Educação. É para destacar esse momento de instauração que vi a necessidade de me reportar a momentos articuladores da trajetória histórica de grandes expressões filosófico-antropológicas da Filosofia da Educação no contexto da cultura ocidental. Essa retomada apresenta-se-me não apenas como uma circunstância contextuante, mas como uma exigência propriamente filosófica, por entender que também o pensamento se constitui historicamente, não sendo possível compreender suas manifestações atuais sem acompanhar sua gênese e formação. No entanto, o objetivo do pre- 
sente trabalho é refletir sobre o sentido em si da educação, frente a suas modificadas relações com a ética e a política, tais como essas dimensões foram vistas até hoje.

Nunca é demais lembrar que a Filosofia da Educação não é uma revisita à história da Filosofia. 0 seu objeto de preocupação e estudo são as condições reais da educação, tais como se desenham a cada momento histórico, e o recurso às referências históricas só se justifica quando se precisa estabelecer algumas balizas contextuais ou quando se trata de evidenciar a historicidade das manifestações lógico-conceituais do pensamento humano. Tratase, pois, de uma reflexão analítica e crítica sobre a problemática da educação, com o propósito de tentar decifrar o seu sentido possível. Entretanto, por outro lado, é também oportuno lembrar que, embora precise considerar os conhecimentos produzidos pelas Ciências da Educação e pelas Ciências Humanas, a perspectiva filosófica é diferente dessas ciências, dada sua intenção de buscar fundamentos, entendidos estes como nexos conceituais explicativos. Isso justifica a démarche filosófica como exercício mais autônomo da subjetividade em relação a procedimentos metodológicos e técnicos e a abordagens empíricas dos fenômenos, objetos das ciências. A questão fundamental que cabe à Filosofia da Educação responder é aquela do sentido e da finalidade da educação. Em assim sendo, sua perspectiva é diferente daquela da Sociologia da Educação, da Psicologia da Educação, da História da Educação, da Economia da Educação etc., encarregadas de estudar os fatos educativos sob os diversos aspectos de suas manifestações concretas.

\section{A educação sob o signo da ética}

0 testemunho da história da filosofia autoriza a afirmar que a educação foi primeiramente pensada como formação ética. De fato, o discurso filosófico da Antiguidade e da Medievalidade sempre concebeu a educação como proposta de transformação aprimoradora do sujeito humano. De imediato, essa proposta se radica na pressuposta universalidade da natureza humana e a educação é vista como formação ética.

Ainda que etimologicamente ética e moral retirem seu sentido de costume (ethos, em grego, e mos, em latim) e este, por sua vez, do habitat, da moradia habitual, estrutura modal dos seres vivos de habitar o mundo, o conceito quer designar, no categorial filosófico, uma qualidade do sujeito humano como ser sensível aos valores, com um agir cuja configuração se deixe marcar por esses valores a que sua consciência subjetiva está sempre se referindo. Sensibilidade axiológica que, do ponto de vista de sua experiência pelo sujeito, é análoga à sensibilidade epistêmica da razão. Característica específica dos seres humanos, ela precisa ser cultivada e sustentada, pois, tanto quanto o conhecimento, essa experiência não é fruto da ação exclusiva das forças vitais e instintivas do ser vivo. Dai o papel primordial que é atribuído à educação: empreendimento ético-formativo, processo de autoconstituição do sujeito como pessoa ética. É a paidéia proposta no quadro da cultura clássica grega e latina.

No entanto, desse processo de constituição do sujeito ético, não estão ausentes, na Filosofia antiga e medieval, as alusões às dimensões social, política, comunitária da existência histórica dos seres humanos. Basta citar como exemplos as clássicas obras $A$ república, de Platão, e a Politica, de Aristóteles. No entanto, todas as referências ao político, que são feitas nessas e em outras obras, direcionam-se à ação dos indivíduos. A política fica como que condicionada à ética, ou seja, à qualidade e à intensidade do aprimoramento da postura e das ações morais das pessoas individuais. A boa qualidade da pólis está na dependência direta da qualidade da vida individual dos seus habitantes. Platão, ao construir seu modelo da cidade ideal, desenvolve uma proposta filosófica de uma pedagogia ético-política, na qual o conhecimento e a prática da virtude vão garantir a viabilidade e a legitimida- 
de do Estado. Para Platão, a educação, se praticada pela razão procedendo dialeticamente, torna-se o fundamento e a sustentação da justiça. Entretanto, a justiça nada mais é do que a dimensão social da virtude, o princípio da ética social que sustenta a vida digna da comunidade. A sociedade justa se sustenta nos princípios da ética.

Primeiro a estabelecer uma Filosofia da Educação na cultura ocidental, de acordo com parecer de Moreau (1978), Platão via a educação como a necessária formação do espírito. Ao ensino, cabia o conhecimento em geral, mas a educação visava uma boa conduta de vida, a virtude. A grande questão era como formar os homens de bem e levá-los ao conhecimento do bem assim como à sua prática. Em pauta, pois, como lembra no Banquete, “... a transcendência soberana do espírito” (Platão, 1979, 205-212).

Também a idéia aristotélica de política está intrinsecamente vinculada a um fundamento ético. É bem verdade que, muito mais que Platão, Aristóteles valoriza a realidade empírica do Estado e a condição social do indivíduo. Sua célebre fórmula de que "o homem é, por natureza, um animal político" (Política, 1, 1. 1253a 3; 11l, 6, 1278b 19; Ética a Nicômaco, 1. 7, 1097b 11) sintetiza bem seu pensamento a respeito. Quis dizer com isso que o indivíduo não basta a si mesmo. No entanto, Aristóteles também é incisivo em afirmar que a finalidade da pólis não é apenas biológica, mas sobretudo moral (Política, 111 9, 1280 b 13-17). A cidade é antes o ambiente em que pode ser realizada, graças à independência que ela assegura, o ideal de uma vida perfeita, o lugar onde o homem pode atingir a felicidade pelo exercício da virtude, no respeito da justiça (Política, 111, 9, 1289 b 30). Afinal, o fim do Estado não é propriamente nem a defesa comum nem a organização das trocas, mas o reino da justiça (Política, 1, 2, 1253 a 37-38). No entanto, apesar desse avanço, Aristóteles continua entendendo que a formação ética do indivíduo é o único caminho para a virtude, para cujo desenvolvimento as estruturas político-administrativas devem fornecer as condições objetivas e a educação, as subjetivas.
A relação íntima da educação com a formação ética, de acordo com o essencialismo típico da filosofia grega, consolida-se com a teoria do ato e da potência, pois a educação não será nada mais do que um processo de atualização das potencialidades do ser humano, uma vez que a infância é a idade adulta em potência. As posições aristotélicas são ainda mais reforçadas nessa direção com sua apropriação pela Teologia cristã, graças ao profundo trabalho filosófico de São Tomás de Aquino, que incorpora o aristotelismo de modo análogo ao que Agostinho fizera com o platonismo. Na própria Ética a Nicômaco, Aristóteles (1973) enfatiza as referências à vida política, à inserção na sociedade. Diz ele: “... o objetivo da vida política é o melhor dos fins, e essa ciência dedica o melhor de seus esforços a fazer com que os cidadãos sejam bons e capazes de nobres ações" (p. 259, passagens 1.1099 b-30). Entretanto, toda sua investigação visa explicitar o bem para se viver com felicidade e justiça. 0 homem precisa da virtude para inserir-se na sociedade.

Assim, a idéia-força que predomina na Filosofia da Educação na Antiguidade é que a dimensão política é inteiramente derivada da qualidade ética dos sujeitos pessoais. É por isso mesmo que, desde Sócrates, a ética é a força motriz de todo investimento pedagógico. Trata-se de levar o aprendiz a incorporar uma típica atitude espiritual, dar-lhe consistência e permanência de modo que possa tornar-se fonte reguladora de seu agir, que passará a qualificar-se como agir moralmente bem. E se todos os indivíduos se tornarem pessoas éticas, a cidade, a pólis, será igualmente uma comunidade justa. 0 político decorre do ético, nele encontrando seu fundamento. A ética assume lugar tão relevante na filosofia socrática que todo o empenho essencial do conhecimento deve ser aquele que visa descobrir o bem. A natureza do homem passa a ser objeto do conhecimento filosófico na exata medida em que aspira ao bem, ao comportamento virtuoso. Virtude e bem são os efetivos critérios e guia para toda ação pessoal e, conseqüentemente, 
também para a vida na cidade. Não é por outra razão que o modelo de sociedade proposto por Santo Agostinho, em A cidade de Deus, como lugar da verdadeira felicidade, é aquele que é constituído por homens virtuosos. Virtuoso é o homem que escolhe o caminho do bem para viver, como esclarece o próprio Santo Agostinho em seu outro texto, Do livre arbitrio.

É essa maneira de entender a natureza do homem como ser ético que explica a força do conceito de alma na filosofia de lastro socrático, bem como da importância que nela assumirá a categoria de substância essencial. A alma, como a substância humana, é o sujeito da ética e o seu cuidado é o que há de mais divino no homem, cuidado a ser exercido mediante o conhecimento dos valores da bondade e da verdade.

Com base nessas noções de alma e de bem, a ética socrática, objeto por excelência da educação, busca atingir a interioridade humana, centro em que se encontra a lei do autodomínio, da ordenação dos valores, da virtude e da felicidade. Domínio do homem sobre si mesmo, o que o eleva à liberdade moral como autonomia frente à sua co-natureza animal. Com a impregnação profunda da cultura helênica pelo Cristianismo, a natureza da educação como essencialmente formação ética ganhou ainda mais força, como podemos ver na obra dos Padres da Igreja e, destacadamente, em Santo Agostinho e São Tomás de Aquino.

Nessa tradição da Filosofia, a educação é vista como garantindo a humanização do homem na medida em que ela possa contribuir diretamente para a construção do próprio sujeito. A imagem é dada pela metáfora da identidade e da autonomia do sujeito espiritual, individual, pessoal que, princípio de atividade, atua pela força energética de sua vontade livre. A transformação do mundo, a construção da sociedade, o aprimoramento da existência objetiva, decorrem agora diretamente da transformação, do aprimoramento íntimo do sujeito. A pólis, como cidade justa e democrática, será resultante das ações, eticamente respaldadas, postas pelos indivíduos transformados. 0 direito positivo só pode se legitimar se fundado em diretrizes éticas, âmbito em que deve prevalecer a dignidade subjetiva da pessoa humana.

Nessa tradição de valorização da autonomia subjetiva, a educação é sempre entendida como um investimento feito pelos sujeitos, dos recursos da exterioridade, com vistas ao desenvolvimento de sua interioridade subjetiva. A educação identifica-se então com o próprio método do conhecimento, com o exercício da vivência da consciência, uma vez que educarse é apreender-se cada vez mais como sujeito, buscando agir com vistas a realizar-se cada vez mais como tal. 0 ético predomina sobre o político, atuando o educacional como mediação. É por isso que essa orientação enfatiza mais os fundamentos antropológicos e éticos dos processos do que suas mediações práticas ou suas implicações políticas.

\section{A educação como formação política}

Sem dúvida, pode-se afirmar com segurança que o lluminismo, como amplo movimento cultural e filosófico que aconteceu na Europa na era moderna, ao instaurar sua proposta pedagógica, retoma as idéias da natureza humana, da autonomia racional e moral do indivíduo e da perfectibilidade humana. No entanto, por outro lado, essas categorias têm seu sentido profundamente modificado. Marcado pela longa, lenta e sofrida constituição da moderna sociedade burguesa e mercantil, que vai se distanciando cada vez mais do mundo feudal e cristão, o pensamento iluminista se instaura sob o crescente impacto da formação dos estados como entidades políticas autônomas. A consciência ética se confronta agora com a realidade da vida política que não é mais mera circunstância na existência dos indivíduos mas, ao contrário, é uma forte e densa realidade autônoma, ditando e impondo regras e leis. Agora, a legitimação da existência não se sustenta apenas na conformação à lei interior do espírito, mas também necessariamente num acordo com a lei exterior estabelecida, autonomamente, pela 
sociedade. É preciso doravante considerar também os dispositivos do contrato social. E essa sociedade determinante não se apresenta como entidade aprioristicamente definida, mas como processo histórico real a ser empiricamente abordado e esquadrinhado. Recusando o modo metafísico de pensar, a filosofia moderna opõe-se também à ética essencialista da vida puramente interior.

Jean-Jacques Rousseau e Immanuel Kant podem ser tomados com os mais significativos representantes dos construtores do projeto iluminista da modernidade no que se refere a essa perspectiva de uma outra pedagogia de acordo com a qual a formação humana, visada pela educação, passa necessariamente pela consideração da condição natural do homem como ser social. A filosofia moderna refere-se aos indivíduos, mas pressupondo-os como partes integrantes de um corpo social que os atravessa de fora a fora. Consciência, liberdade moral, perfeição humana, vontade livre são dimensões relacionadas à vida dos indivíduos, mas elas só ganham consistência plena com a inserção dos indivíduos na estrutura social. É por isso que as propostas pedagógicas de Rousseau (1968) não podem ser plenamente compreendidas separadas de sua teoria política (Rousseau, 1999). Do mesmo modo, a proposta educativa de Kant não faz sentido separada de sua visão do destino da civilização humana como um todo. Desse modo, na modernidade, o critério fundamental da educação, o aspecto que recebe maior ênfase na formação humana, é aquele da formação política, a formação do cidadão, entendida esta à luz de seus pressupostos antropológicos e epistemológicos do racionalismo naturalista. Como bem o resume Lyotard,

[...] a educação tem uma finalidade explícita na modernidade do fim do século XVIII. É a do projecto geral das Luzes: libertar a humanidade do despotismo, do despotismo político, mas também da ignorância e da miséria [...]. A educação tem pois uma intenção fundamental: [...] fazer com que a nação, a comunidade de facto, se torne numa República de direito. (apud Kechikian, 1993, p. 49)
Para Kant (1996), “a educação prática e moral é aquela que diz respeito à construção do homem, para que viver como ser livre [...] o qual pode bastar-se a si mesmo, constituir-se membro da sociedade" (p. 20). Ainda que se trate de aprimorar o homem em sua individualidade, tal objetivo diz respeito ao seu viver em sociedade, sua ineludível moradia. Na Modernidade, são todas as modalidades da vida que assumem mais explicitamente essa dimensão política.

Essa condição do homem viver em sociedade modifica profundamente o seu processo de auto-aperfeiçoamento, pois seu aprimoramento ou sua degradação não mais dependem apenas da lei interior de sua vontade, mas também das determinações exteriores da vida social. Assim, o 'instinto divino da consciência', de que fala Rousseau, que é fonte da excelência moral do indivíduo, confronta-se com as exigências da vida em sociedade, esfera da liberdade civil. É por isso que o homem que "nasce livre, por toda parte encontra-se a ferros” (Rousseau, 1999, p. 53). Parafraseandose os metafísicos clássicos, pode-se afirmar que, na modernidade, o social é o elemento que constitui a substância da essência humana, não é mais um mero acidente.

De acordo com os princípios filosóficos de Rousseau (1958), o homem só pode ser bom numa sociedade racional. A finalidade da educação é a reconstrução do homem, por isso mesmo, ela pode ser até 'desnaturação'. Ela deve "dar às almas a forma racional e dirigir de tal forma as suas opiniões e gostos que sejam patriotas por inclinação, paixão e necessidade" (cap. 4, p. 605). A cidade deve ser sobreposta a tudo mais. A liberdade consiste na obediência total à lei da cidade ideal (Chateau, 1956).

Essa participação do elemento social na natureza intrínseca do modo de ser humano torna-se marca característica da antropologia fundante da compreensão da educação no século XIX, constituindo a base central do conhecimento que, nessa fase, já se constitui como conhecimento científico, graças à emergência das ciências humanas. É que, ao lado da 
expressão filosófica, dando-se como filosofia social ou filosofia política, as ciências humanas se instauram fundamental e preponderantemente como ciências sociais. E sob as inspirações de todos os paradigmas epistemológicos daquele momento, o pensamento teórico se manifesta enfatizando a primazia do social.

É o que podemos conferir na obra de Émile Durkheim. Na esteira da perspectiva positivista, inaugurada por Auguste Comte, Durkheim dedica todo o seu engenho em mostrar a consistência e a centralidade do social como elemento explicativo do modo de existir humano. 0 social não reduz jamais ao individual nem a Sociologia a uma Psicologia de grandes número de indivíduos. Sua obra teórica sistematiza a solidariedade social, o trabalho social, a consciência coletiva, a anomia social, enfim, a vida autonomizada da sociedade, uma entidade que, embora formada pelos indivíduos, tem uma realidade própria, distinta. É independente das condições particulares dos indivíduos; estes passam, ela permanece. É sob a prática do trabalho que os indivíduos se vinculam intrinsecamente à sociedade, fortificados por uma solidariedade orgânica que os mantém unidos, como se estivessem atraídos por uma força centripeta. Por isso mesmo, a realização dos indivíduos em particular depende da boa realização da sociedade. Só que essa realização está sempre ameaçada pela anomia que pode impedir que a sociedade preencha sua função de regulação e controle.

De igual modo, o pensamento de outro grande profeta da modernidade, Max Weber (1864-1920), segue a mesma linha de consagração da prevalência das leis impessoais da sociedade. Weber (1974) enfoca a política como tema central de sua obra, fazendo uma análise profunda e completa da modernidade. Busca explicitar as leis das ações humanas. Embora muito cauteloso para evitar uma entificação da sociedade mediante o uso de categorias coletivas, preocupado em livrar as ciências históricas dos pressupostos metafísicos do idealismo alemão, Weber vê na ação racional, mediada pelos tipos ideais, critério da prática que independe da vontade individual dos agentes. Um sistema político e econômico que - com uma lógica própria: a da racionalidade - dita leis para o comportamento humano.

É certamente na obra de Karl Marx (1818-1883) que o caráter determinante da essência humana pelo social é mais assumido teoricamente e justificado, questionando, de vez, qualquer referência metafísica de caráter essencialista. Herdeiro da tradição dialética hegeliana, Marx e Engels (1997) vê o homem se constituindo historicamente mediante seu agir prático coletivo. Em que pese seu idealismo metafísico exacerbado e romântico, Hegel já havia integrado em sua síntese filosófica a participação do processo histórico real da sociedade humana e de sua manifestação política sob a forma do Estado, como figuras substanciais da realização do Espírito Absoluto. Escoimando o hegelianismo dessas dimensões metafísicas, que entende ser puras ilusões ideológicas, Marx incorpora a dialeticidade do processo histórico real que se realiza na história da sociedade humana. Muito sensível, por outro lado, à dura realidade histórica e social de sua época, quando o modo de produção capitalista já se encontra em pleno vigor, Marx adentra-se, sob a perspectiva da ciência histórica, no estudo da economia política, solo da efetiva realização dos seres humanos. Analisando as condições reais em que se dá a produção concreta da existência humana sob os ditames da economia capitalista, Marx explicita a tragédia da existência histórica do homem como despossuído de sua essência pela alienação do trabalho imposta pelas 'leis' da produção material. E para chegar à realização de si mesmo como homem inteiramente emancipado e totalmente humano, a partir de sua condição de ser natural, de ser sensível num mundo sensível, os homens que se alienam em sua história coletiva só podem engendrar-se como homens por meio de seu trabalho humano. 0 trabalho, dinâmica responsável pela efetiva condição do modo de ser humano, só é realizável no 
contexto histórico-social. Se, de um lado, ele é o lugar da alienação, da perda da essência, ele é também o único espaço para a realização do humano. Os homens são seres ativos, práticos, produtores de objetos sensíveis, não em sua condição de gênero universal, mas em sua existência histórica e social, em sua realidade, constituída pelo conjunto de suas relações sociais. 0 trabalho, como força engendradora do indivíduo humano e meio de produção e reprodução da existência, pressupõe a presença efetiva dessa rede de relações sociais com um mínimo de eqüidade e liberdade, o que exige a permanente luta política revolucionária contra todas as formas históricas de opressão, numa sociedade burguesa e capitalista, hierarquizada e cristalizada em classes sociais, com interesses objetivos conflitantes. Para Marx, o homem se define em sua humanidade pela relação com a natureza e com a sociedade. Ele não é um indivíduo solitário nem um elemento avulso da humanidade em geral, mas um ser histórico e social, cujo perfil concreto é definido pelas leis provisórias de um determinado modo de produção. Marx pensa a reificação e a alienação como conseqüências de modos históricos de produção e não como determinações essenciais do homem em geral, pois aceitar isso seria recair na reificação e na alienação. A concreta realidade humana não é resultante nem da realização da ldéia ou do Espírito $A b-$ soluto (Hegel) nem da consciência racional dos homens, de suas vontades puras e reflexões abstratas (Metafísica clássica e ldealismo moderno), mas do real movimento histórico das forças produtivas, desencadeado e sustentado pelos homens a partir das contradições permanentes que devora suas entranhas.

Essas grandes sínteses filosóficas, aqui apenas tangenciadas, produzidas por Marx, Weber e Durkheim, em que pesem as diferenças de seus pontos de partida e de apoio, têm um ar de família e a grande referência comum é a marca fundante do social na constituição da efetiva realidade do ser humano, contrapondose os três pensadores, de forma radicalmente igual, a toda pretensão metafísica. Com essa incisiva afirmação da centralidade nuclear da prática social, manifestando-se historicamente, a presença das contribuições desses pensamentos, feitas todas as necessárias ressalvas, tornou-se elemento de todas as ciências humanas e de toda filosofia crítica da atualidade.

Não é, pois, sem razão que essa perspectiva marcou profundamente o modo de se compreender a educação na virada do século XIX e no início do século XX. Ainda que a temática educacional não tenha recebido um tratamento explícito nessas obras, é evidente que, por decorrência intrínseca, a educação só tem sentido sob as mesmas referências, como modalidade do próprio processo social. É o que explica e justifica porque as ciências sociais vão passando a ocupar, no período, o lugar das ciências psicológicas na explicação do fenômeno educacional. E não se pode legitimar a intervenção pedagógica a não ser sob uma justificativa política, de ordenação do social.

Tanto quanto os antigos e os medievais, os pensadores modernos vão aproximar verdade $\mathrm{e}$ bem, aproximando o conhecimento racional da prática educacional. Só que agora a razão é tomada na sua condição de potência natural, atuando por conta própria sem qualquer intervenção de ordem sobrenatural. 0 homem volta a ser a medida de todas as coisas e não mais Deus. Esse antropocentrismo radical, colocando o homem racional no centro e na direção de um mundo desencantado, laiciza o olhar e o agir das pessoas. Isso dá uma outra dimensão para a vida social e para as instituições políticas, modificando profundamente o sentido da educação. Nesse momento, para se formar bem o indivíduo, é preciso considerar a sociedade estruturada como condição substantiva do existir humano. 0 homem não pode ser eticamente bom, contando apenas com uma eventual coerência com os valores de sua subjetividade e muito menos com a obediência a preceitos divinos sobrenaturais. Antes, precisa integrar-se adequadamente à sociedade, à pólis. E antes de mais nada cabe à educação propiciar, de modo sistemático, as 
condições para essa integração. Inserção não mais à 'cidade de Deus', mas à 'cidade dos homens'. Por isso mesmo, a educação passa a assumir, ao longo da Modernidade, o caráter de uma ação e de uma prestação pública, definindo-se como mediação própria para a constituição da cidadania. E seu grande instrumento é o conhecimento racional. Não mais o conhecimento metafísico das essências das coisas, mas o conhecimento científico dos fenômenos naturais, única e exclusiva manifestação do real. E agora a Filosofia, de serva da Teologia que era na ldade Média, passa a ser 'serva da ciência', exercendo-se fundamentalmente como reflexão metacientífica. É compreensível que só na Modernidade a filosofia se desse conta da extrema relevância do social para a própria constituição do sujeito pessoal, considerando a sociedade como condição fundamental para a vida moral das pessoas. Em que pesem já os avanços organizacionais da sociedade pré-moderna, ela não foi muito além de uma 'comunidade natural', ainda não política. Essa condição só se tornou possível no período moderno, expressando-se fundamentalmente na constituição dos Estados, como entidades específicas e autônomas de gerenciamento da vida social.

\section{Educação e formação cultural na contemporaneidade}

Esse panorama está em processo de mudança, agora, na contemporaneidade. Uma nova forma de se compreender a educação: nem mais sob a prevalência de uma teleologia ética nem mais sob a perspectivação política. Tanto a ética como a política estão sendo questionadas como referências básicas da educação. Como se trata de um pensamento ainda em construção, fica difícil, por falta de distanciamento, apreendê-lo em toda sua extensão, profundidade e magnitude. Essa nova orientação vem sendo designada de filosofia pósmoderna ou pós-estruturalista, substrato filosófico de uma possível nova era histórico-cultural: a pósmodernidade. Levada a seus extremos, tal tendência cai no irracionalismo, inviabilizando qualquer alcance construtivo da racionalidade humana. Seu irracionalismo potencial emerge com a acusação que faz aos comprometimentos da razão com o poder opressivo sobre o homem, da hostilidade da razão à vida. A razão acaba sendo vista apenas como agente de repressão e não instância de libertação, como o pretendia o lluminismo. Os germens dessa crítica radical surgiram na própria Modernidade, com Nietzsche, Freud e Marx, mas se consolidam no pensamento atual, com Foucault, Deleuze, Guattari, Lyotard, Beaudrillard e Maffesoli, entre outros pensadores.

Como acertadamente observa Rouanet, há nessa atitude crítica radical um forte núcleo de verdade:

Depois de Marx e Freud, não podemos mais aceitar a idéia de uma razão soberana, livre de condicionamentos materiais e psíquicos. Depois de Weber, não há como ignorar a diferença entre uma razão substantiva, capaz de pensar fins e valores, e uma razão instrumental, cuja competência se esgota no ajustamento de meios e fins. Depois de Adorno, não é possível escamotear o lado repressivo da razão, a serviço de uma astúcia imemorial, de um projeto imemorial de dominação da natureza e sobre os homens. Depois de Foucault, não é lícito fechar os olhos ao entrelaçamento do saber e do poder. Precisamos de um racionalismo novo, fundado numa nova razão. (Rouanet, 1987, p. 12)

Não integra o objetivo deste ensaio aprofundar as posições dessa tendência em gestação na filosofia contemporânea, até porque eu a vejo como diretamente tributária da crítica desenvolvida pelos teóricos da Escola de Frankfurt. Com efeito, é possível identificar nas formulações da Teoria Crítica, da Escola de Frankfurt, as referências históricas e teóricas dessa inflexão que marca a entrada da cultura e da filosofia ocidentais na era contemporânea. Cabe atribuir-lhe, com toda legitimidade, esse papel, pois foi dela a iniciativa histórica de apresentar, de forma sistemática, o balanço inaugural de toda a produção filosófico-científica da modernidade, deslanchando um acerto 
de contas que ainda não terminou e que ainda continua sendo retomado e prolongado na atualidade. Não é por acaso que a filosofia frankfurtiana nasce e se constitui como diálogo, competente e crítico, com as heranças do positivismo, do neokantismo, do hegelianismo e do marxismo.

Como bem o assinala Goergen (2001), é preciso atentar que as posições frankfurtianas, embora "em muitos momentos assumindo traços de uma crítica radical à racionalidade, pretende, na verdade, salvar a razão das armadilhas de sua instrumentação e de seu uso contra o próprio ser humano. Distingue-se, portanto, das teses pós-modernistas, críticas da própria razão moderna e não apenas de seu mau uso. Para os pós-modernos, a razão iluminista, com seus traços de teleologia progressista, firmada em seu manejo adequado, perdeu, ela própria, sua legitimidade" (p. 23). Habermas (1990) defende que a razão comunicativa assegura o exercício de uma racionalidade processual, aberta à contingência e à pluralidade sem abandonar as pretensões de validade universal: "a unidade da razão na multiplicidade de suas vozes” (p. 151).

Minha idéia é de que as posições teóricas elaboradas pelos pensadores frankfurtianos, particularmente por Adorno e Horkheimer, inauguram uma concepção diferenciada da educação, que não se expressaria mais nem como formação ética do sujeito pessoal nem como formação política do sujeito coletivo, mas como formação cultural, conceituada como realização antropológica tout court, sem qualquer adjeti-vação de qualquer natureza. $\mathrm{E}$ no rastro dessa idéia originante, a grande maioria das manifestações da filosofia contemporânea vai avançando no sentido de se conceber essa formação como a própria substância da educação.

Adorno (1985) defende a idéia de que a sobrevivência da Filosofia exige a renúncia à busca de qualquer significado predeterminado das coisas, pretensão que até a Modernidade ficara a cargo de uma razão que se revelava totalitária, globalizante e mistificadora para com o ser humano concreto, toda vez que se propunha delinear esse sentido. É o que já fala em sua aula inaugural sobre "a atu- alidade da filosofia”, de 1931, e que volta a ser enfatizada em Dialética do esclarecimento, de 1947, em Dialética negativa, de 1966, e em Teoria estética, de 1970. A razão transforma-se numa razão instrumental, ferramenta por excelência da ciência e da tecnologia. Ética e política perdem toda sua densidade e sustentação em decorrência dessa hipertrofia do racional puro, que exorcizou o corpo e desencantou o mundo. Isso impediu que se pudesse falar da perfeição moral do sujeito pessoal e de qualquer futuro político formulável. Resta ao filósofo um trabalho teórico crítico, calcado numa negação radical da realidade presente, ainda justificando a luta contra todas as formas de dominação, desde que renuncie à tentação da universalidade e da totalidade, tanto no campo ético como político. Tal a única maneira de garantir uma autonomia do sujeito num contexto onde haja igualmente a liberdade de todos.

0 pensamento crítico contemporâneo tende a questionar radicalmente tudo aquilo que era a própria sustentação do edifício filosófico da modernidade, a pedra fundamental da racionalidade emancipadora e altaneira (Kant, 1996), arrastando consigo os ideais iluministas da ética e da política. Por isso mesmo, não podia deixar de recuperar as perspectivas dionisíacas da filosofia a marteladas de Nietzsche, bem como não poderia deixar de voltar-se para a estética, via privilegiada de resgate da corporeidade e o lugar possível do sentido encarnado. Pode-se então afirmar que a contemporaneidade cultural e filosófica, inaugurada por essa crítica, instala-se tendo como mote a paráfrase bermansiana da fala de Marx no Manifesto do Partido Comunista, de 1851: "tudo o que é sólido desmancha no ar...". Nada

1. Marshall Bermann (1996) simplificou o texto de Marx (1977) que era mais complexo no original. Na melhor tradução a que tive acesso, Marx escreveu: "Tudo o que era sólido e estável evaporou-se no ar, tudo o que era sagrado é profanado, e por fim os homens são obrigados a encarar com serenidade suas verdadeiras condições de vida e suas relações com os demais homens" (Manifesto do Partido Comunista, 1977, p. 87). Encarar com serenidade suas verdadeiras condições de vida e suas relações com os demais homens, depois de derrubados todos os ídolos e mitos, eis uma intenção de descrever a situação de há 150 anos atrás... mas não pode haver descrição melhor da situação enfrentada hoje pela humanidade, apesar de todas as mudanças ocorridas desde então... 
mais se sustenta do edifício filosófico-científico da modernidade, a não ser seu lado sombrio e irracional, que é aquele da mais perversa e destrutiva dominação. Uma significativa vertente da filosofia contemporânea vai se constituindo, então, como denúncia e recusa de todas as modalidades de metanarrativas, de todos os dogmas e discursos da racionalidade, estejam elas nas ciências, na filosofia ou em qualquer outro lugar da cultura. Junto com essa denúncia da instrumentalidade da razão e de suas graves conseqüências para a vida humana, a reflexão crítica dos frankfurtianos, Adorno à frente, resgata a experiência estética, como vivência subjetiva da corporeidade mediante o exercício de seus sentidos, enfatizando sua importância como experiência primordial do homem, até então danificada pelo uso puramente instrumental da razão ao lidar com as coisas humanas. A experiência estética constitui o último modo de resistência dos indivíduos à desenfreada opressão causada universalmente pela racionalidade técnica da sociedade capitalista contemporânea.

Os ecos da inspiração frankfurtiana, além de tornar audíveis as invectivas nietzscheanas em pleno final do século XX, ressoa por todo o ambiente cultural e filosófico da atualidade, suscitando novos 'jogos de linguagem', que se apresentam tão somente como nichos de experiência de conhecimento, sem qualquer ambição de expor verdades inquestionáveis.

0 núcleo de verdade do novo conceito de educação se expressa, pois, como a própria formação do sujeito. No entanto, alguns prévios cuidados esclarecedores precisam ser tomados em decorrência da ambigüidade e ambivalência dos signos lingüísticos, pois como já ensinava o mestre de Santo Agostinho, "nada pode ser ensinado sem signos, mas os signos não ensinam nada" (Sobre $o$ mestre). 0 termo formação é onipresente nas diversas conceituações de educação, mas o mais das vezes para contrapor-se à informação. Outras vezes, arrasta consigo a conotação do pôr em forma, moldar, sentido que é exatamente o contrário daquele em que está sendo tomado aqui. 0 sentido aqui é exatamente aquele da constituição do sujeito que não tem molde onde se encaixar, para se enquadrar, medidas para se medir. Um sujeito totalmente contingente, com muito precárias referências históricas para se guiar em sua existência. Precisa ser, ou melhor, vir-a-ser sem que caminhos precisos estejam previamente traçados.

lgualmente o conteúdo cultural, no contexto ora em questão, não denota apenas sua significação de ilustração, de erudição literária, de performance artística etc., mas envolve todas essas dimensões desde que elas estejam articuladas na experiência vivenciada da auto-reflexão crítica, na autonomia do sujeito humano como praticante do exercício público da racionalidade, uma vez superados os limites da liberdade impostos pela semicultura (Pucci, 1995), ou seja, é culturalmente formado, portanto educado, o homem que dispõe do esclarecimento, com o qual se identifica, pois, a própria educação. No categorial frankfurtiano, a semicultura é o embotamento da cultura, a alienação, a padronização, o conformismo, situações em que se encontram os homens por renúncia, subserviência ou dominação. Dito de outro modo, é própria barbárie que, na visão de Adorno, é "o preconceito delirante, a repressão, o genocídio e a tortura" (Tabus apud RamosOliveira, 1995, p. 92-93).

0 conceito adorniano de formação cultural, embora forjado a partir da sua vivência no contexto da cultura alemã (Pucci; Ramos-Oliveira; Zuin, 2000), ganha um alcance mais amplo, tornando-se uma fecunda categoria de análise da vida social contemporânea. A Bildung, como lado subjetivo da Kultur, só se legitima como exercício de juízo existencial crítico e autocrítico, de caráter emancipatório, indo além da semiformação, Halbebildung, definição de uma produção simbólica em que prevalecem a adaptação e o conformismo, típicos da cultura massificada.

A proposta e, até certo ponto, a aposta frankfurtiana de uma educação emancipadora vinculam-se à afirmação da intrínseca necessida- 
de de uma crítica permanente. Após Auschwitz, impõe-se uma reelaboração do passado, uma severa crítica do presente, se se almeja um futuro mais humanizado. E ao mesmo tempo em que Adorno alerta para os riscos de um processo educacional pautado apenas nas luzes da consciência (pura formação ético-epistêmica), sem considerar sua orientação social, chama a atenção para os igualmente graves perigos do comprometimento do ético frente à determinação social (pura formação política). 0 desafio que se apresenta é o de "pensar a sociedade e a educação em seu devir. Só assim seria possível encontrar alternativas históricas capazes de assegurar a emancipação de todos, tornando-os sujeitos da histórica, aptos a vencer a barbárie e a realizar o conteúdo emancipatório do movimento de ilustração da razão" (Maar, 1995, p. 12). A proposta da educação como formação cultural destaca que a educação não concerne apenas a formação da consciência de si, como aperfeiçoamento moral, mas nem por isso reduz-se a mero enquadramento social, pura determinação política. "A educação tem sentido unicamente como educação dirigida a uma auto-reflexão crítica" (p. 121).

Adorno (1995) explicita sua concepção de educação:

Evidentemente não a assim chamada modelagem de pessoas, porque não temos o direito de modelar pessoas a partir de seu exterior; mas também não a mera transmissão de conhecimentos, cuja característica de coisa morta já foi mais do que destacada, mas a produção de uma consciência verdadeira. lsto seria inclusive de maior importância política; sua idéia, se é permitido dizer assim, é uma exigência política. Isto é: uma democracia com o dever de não apenas funcionar, mas operar conforme seu conceito; demanda pessoas emancipadas. Uma democracia efetiva só pode ser imaginada enquanto uma sociedade de quem é emancipado. (p. 141-142)

Para Adorno (1995), o conhecimento tem papel fundamental no processo educativo.
No entanto, impõe-se entender bem o sentido da razão e da subjetividade. Em geral, o conceito de racionalidade ou de consciência

[...] é apreendido de um modo excessivamente estreito, como capacidade formal de pensar. Mas esta constitui uma limitação da inteligência, um caso especial de inteligência, de que certamente há necessidade. Mas aquilo que caracteriza propriamente a consciência é o pensar em relação à realidade - a relação entre as formas e estruturas do pensamento do sujeito e aquilo que este não é. Este sentido mais profundo de consciência ou faculdade de pensar não é apenas o lógico-formal, mas ele corresponde literalmente à capacidade de fazer experiências. Eu diria que pensar é o mesmo que fazer experiências intelectuais. Nesta medida e nos termos que procuramos expor, a educação para a experiência é idêntica à educação para a imaginação. (p. 151)

0 compromisso da educação é com a desbarbarização, é transformar-se num processo emancipatório, no qual ocorra uma luta sistemática pela autonomia, pela emancipação. E sua única ferramenta é o esclarecimento que se constitui como passagem do inconsciente para o consciente, do não ciente para o ciente, do pseudociente para o ciente. 0 esclarecimento ilumina e elimina.

Na perspectiva da Teoria Crítica, o papel da educação é o de assegurar a sobrevivência da formação cultural numa sociedade que a privou de suas bases. É que a industrialização cultural comprometeu essa formação. Cabe aos processos educativos investir na transformação da razão instrumental em razão emancipatória. Por sua vez, a educação pode viabilizar-se, garantindo-se sua fecundidade formativa, se se constituir como exercício da auto-reflexão crítica. Trata-se, para a educação, de produzir uma consciência verdadeira.

Trata-se de uma formação imanente do sujeito da história real da desalienação na história presente, alienada. É que na sociedade industrializada do capitalismo, a educação crítica do individuo, base de sua formação emancipatória, encontra-se travada, realizandose apenas como adaptação, ou seja, como 
semiformação (Adorno,1995), travamento da experiência emancipadora.

A qualificação essencial da educação emancipadora encontra-se na dissecação visceral do nexo entre dominação e racionalidade. A educação crítica só pode realizar-se como reconstrução crítica da racionalidade social, revelando a deformação que produz em face de sua reificação e conduzindo-a a uma clara exposição de suas contradições e, por essa via, apreendendo nela as possibilidades alternativas. Momento de transformação da subjetividade destituída de experiência formativa (Maar, 1995).

\begin{abstract}
A organização social em que vivemos continua sendo heterônoma, isto é, nenhuma pessoa pode existir na sociedade atual realmente conforme suas próprias determinações; enquanto isto ocorre, a sociedade forma as pessoas mediante inúmeros canais e instâncias mediadores, de um modo tal que tudo absorvem e aceitam nos termos dessa configuração heterônoma que se desviou de si mesma em sua consciência. (p. 181)
\end{abstract}

\section{Conclusão}

Tendo em conta a insustentabilidade das referências ético-políticas das tradições metafísica e iluminista, o novo conceito de educação, que vem sendo forjado no contexto da contemporaneidade - questionadas a universalidade, a transcendentalidade e a apoditicidade dos valores -, vai partir da condição de contingência imanente do próprio sujeito. A proposta possível de sua educação é aquela de sua própria formação como sujeito cultural.

Por isso mesmo, no que concerne ao conceito da educação, tal qual vem sendo constituído, a referência passa a ser, não mais a antiga ética, ou a recente política, mas uma nova estética. Não há mais valores éticos referenciais nem muito menos consígnias políticas válidas, conta apenas o novo sentir bem dos sujeitos humanos. Sem dúvida, o cenário da cultura atual é complexo. Sobrevivem e convivem os diversos paradigmas filosóficos a inspirarem as buscas da Filosofia da Educação. Particularmente, faz-se ainda muito forte a marca de uma concepção tecnofuncionalista da educação, colocando-se em nome da ciência e de seu poder tecnocrático, numa ponta do espectro, enquanto que na outra ponta agiganta-se a perspectiva estetizante. $\mathrm{Cu}$ riosamente, esses extremos se tocam e acabam tendo uma paradoxal convivência com um nível de tolerância recíproca muito mais harmonioso do que com a esfera dos paradigmas éticos ou políticos.

No entanto, na verdade, a exacerbação estetizante é mesmo resultante do impulso da radicalidade da crítica à razão instrumental. Sua verdade está na afirmação de que uma nova referência para a educação precisa ser levantada e que nela não se faça ausente a dimensão estética do existir. Entretanto, essa dimensão estética é apenas uma parte do todo, sem dúvida aquela cuja visibilidade é de mais fácil percepção e que, por não ter sido devidamente considerada pela tradição filosófico-educacional, agora faz sua reivindicação de forma mais ruidosa e, às vezes, até mesmo acintosa.

A idéia de formação cultural dá à educação uma finalidade intrínseca de cunho mais antropológico do que ético ou político, num sentido estrito. Até para transformar os indivíduos em pessoas éticas e políticas, a educação precisa efetivar-se como formação cultural. No entanto, em si mesma, a educação não tem como garantir, diretamente, que as pessoas se tornem éticas - ela é uma experiência eminentemente pessoal -, nem como metanoia assegurar o aprimoramento do social - a revolução política é uma experiência exclusiva do sujeito coletivo em sua especificidade. 


\section{Referências bibliográficas}

ADORNO, T.; HORKHEIMER, M. Dialética do esclarecimento. Rio de Janeiro: Jorge Zahar, 1985.

ADORNO, T. W. Educação e emancipação. Rio de Janeiro: Paz e Terra, 1995.

AGOSTINHO, S. A cidade de Deus. São Paulo: Edameris, 1964.

Do livre arbítrio. Braga: Faculdade de Filosofia, 1986.

Confissões/De magistro (Do mestre). São Paulo: Abril Cultural, 1980.

ARISTOTELES. Ética a Nicômaco. São Paulo: Abril Cultural, 1973. (Coleção Os Pensadores, v. IV)

Política. São Paulo: Martins Fontes, 1991.

BERMAN, Marshall. Tudo que é sólido desmancha no ar: a aventura da modernidade. São Paulo: Companhia das Letras, 1996.

CHATEAU, J.-J. Rousseau ou a pedagogia da vocação. In: 208.

. Os grandes pedagogos. São Paulo: Nacional, 1978. p. 171-

GOERGEN, P. Pós-modernidade: ética e educação. Campinas: Autores Associados, 2001. (Coleção Polêmicas de Nosso Tempo, V. 79).

HABERMAS, J. Pensamento pós-metafísico. Rio de Janeiro: Tempo Brasileiro, 1990.

KANT, I. Pedagogia. Piracicaba: Unimep, 1996.

. Resposta à pergunta: que é esclarecimento? In: Textos seletos. Petrópolis: Vozes, 1974. p. 100-117.

KECHIKIAN, A. Os filósofos e a educação. Lisboa: Edições Colibri, 1993.

MAAR, W. L. Introdução. In: ADORNO, T. W. Educação e emancipação. Rio de Janeiro: Paz e Terra, 1995. p. 11-28.

MARX, K.; ENGELS, F. Manifesto do Partido Comunista. In: MARX, K.; ENGELS, F. Cartas filosóficas e outros escritos. São Paulo: Grijalbo, 1977. p. 83-116.

MOREAU, J. Platão e a educação. In: CHATEAU, J.-J. Os grandes pedagogos. Lisboa: Livros do Brasil, 1956. p. 21-39.

PLATÃo. Diálogos. São Paulo: Abril Cultural, 1979. (Coleção Os Pensadores).

República. 2.ed, São Paulo: Abril Cultural, 1979. (Coleção Os Pensadores)

PUCCI, B. (Org.). Teoria crítica e educação: a questão da formação cultural na Escola de Frankfurt. Petrópolis/São Carlos: Vozes/ Editora da Ufscar, 1995.

PUCCI, B.; RAMOS-DE-OLIVEIRA, N.; ZUIN, A. A. S. Adorno: o poder educativo do pensamento crítico. Petrópolis: Vozes, 2000. (Coleçã̃o Educação e Conhecimento).

ROUANET, S. P. As razões do iluminismo. São Paulo: Companhia das Letras, 1982.

ROUSSEAU, J.-J. Emílio. São Paulo: Difel, 1968.

. Do contrato social. São Paulo: Abril cultural, 1999.

. 0 governo da Polônia. In: . Obras. Porto Alegre: Globo, 1958.

WEBER, M. Ensaios de Sociologia. 3. ed. Rio de Janeiro: Zahar Editores, 1974.

Recebido em 25.05.06

Aprovado em 11.09.06

Antônio Joaquim Severino é doutor em Filosofia; livre-docente em Filosofia da Educação. Professor titular de Filosofia da Educação na Faculdade de Educação da Universidade de São Paulo. 